\title{
Correction to: Knowledge Sharing: What Works and What Doesn't Work: A Critical Systems Thinking Perspective
}

\section{Peter Massingham ${ }^{1}$}

Published online: 26 November 2019

(C) Springer Science+Business Media, LLC, part of Springer Nature 2019

\section{Correction to: Syst Pract Action Res (2015) 28:197-228 https://doi.org/10.1007/s11213-014-9330-3}

The article missed to include the article Acknowledgment that should be written as follows:

Acknowledgment The author acknowledges the involvement of Ms Lynne Blackbourn, who was employed as a casual research assistant on the research project associated with the article. Ms. Blackbourn is responsible for running and managing workshops and adjusting the design in response to feedback and observation in the research project associated with this article.

This correction does not impact on the paper content itself, the research findings, or the reader's understanding of the academic material.

The online version of the original article can be found at https://doi.org/10.1007/s11213-014-9330-3

Peter Massingham peterm@uow.edu.au

1 Faculty of Business, University of Wollongong, Northfields Avenue, Wollongong, NSW 2522, Australia 